\title{
Surface roughness implant-retained mandibular bar and ball joint overdentures and adherence of microorganisms
}

\author{
Rocío Valenzuela ${ }^{1}$, Daniel Valenzuela ${ }^{2}$

\begin{abstract}
'University of Barcelone, Spain \& Gastrovital, National Council Science Technology and Technological Innovation, Peru,
\end{abstract} \\ ${ }^{2}$ Jose Faustino Sanchez Carrion National University, Peru
}

Correspondence: Dr. Rocío Valenzuela

Email: violetvaln16@icloud.com

\section{ABSTRACT}

Objective: The aim of this study is to assess the surface roughness of the implant-retained mandibular bar overdenture (BOD) and the implant-retained mandibular ball joint overdenture (BJOD) in jaw and its relation with the adhesion of molds and yeasts and mesophyll aerobe, in time 30 and 180 days in mouth. Materials and Methods: Five-systems titanium bar CARES ${ }^{\circledR}$ and synOcta ${ }^{\circledR}$ Straumann ${ }^{\circledR}$ Dental Implant System, Holding AG Inc., Basel, Switzerland (BOD), and five-systems joint ball Klockner ${ }^{\circledR}$ Implant System; Soadco Inc., Escaldes-Engordany; Andorra (BJOD), were used in two parallel groups of five participants, in an essay to simple blind person. To 30 and 180 days, the overdentures were withdrawn and evaluated the Ra: ųm. SJ-301 ${ }^{\circledR}$ Mitutoyo Corporation Inc., Kanagawa, Japan, and the adhesion of microorganisms (colony-forming unit/ $\mathrm{ml})$. Results: The results were as follows: the $R_{\mathrm{a}}$ : Um $\left(30^{\text {th }}\right.$ and $\left.180^{\text {th }}\right)$ : BOD, 0.965-1.351; BJOD, 1.325-2.384. Adhesion: Molds and yeasts, BOD, $2.6 \times 10^{2}$ and $4.6 \times 10^{3}$; BJOD, $3.0 \times 10^{2}$ and $5.3 \times 10^{4}$. Adhesion: Mesophyll aerobe, BOD, $3.8 \times 10^{6}$ and $5.8 \times 10^{6}$; BJOD, $4.3 \times 10^{6}$ and $7.1 \times 10^{7}$. Conclusions: At 30 days $(P=0.489)$, there were no differences in BOD and BJOD for adhesion of molds and yeasts and mesophyll aerobe between both overdentures. At 180 days $(P=0.723)$, there were differences in the adhesion of mold and yeast and mesophyll aerobe, being greater in BJOD.

Key words: Bacterial adhesion, clinical studies/trials, implantology, overdenture, surface properties

\section{INTRODUCTION}

In the treatment of the mandibular edentulous, the implant-retained overdenture has been shown to have advantages in support, retention, stability, and esthetics, ${ }^{[1,2]}$ improving masticatory efficiency, decreasing anterior bone loss and injury in soft tissues, and increasing comfort, satisfaction, and improvement of the patient's health quality. ${ }^{[3]}$ According to the type of anchorage recommended, we have the implant-retained mandibular bar overdenture (BOD) and implant-retained ball joint overdenture(BJOD). Bar

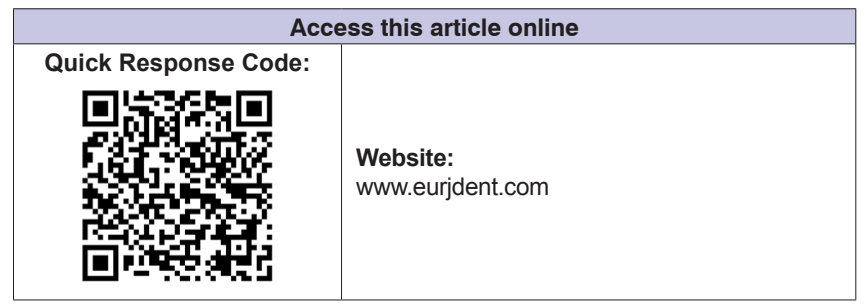

anchors are retention systems that provide adequate support for rehabilitation. ${ }^{[4,5]}$ By the other side, the ball joints are axial anchors with retention system through threaded connections for mandibular prosthetic reconstruction. It is considered that regardless of the retention system, the adjustment must be passive to the implants. ${ }^{[6]}$ The structure of the overdentures consists of thermoplastic poly methacrylates which are derived from ethylene and contain a vinyl group resulting

This is an open access journal, and articles are distributed under the terms of the Creative Commons Attribution-NonCommercial-ShareAlike 4.0 License, which allows others to remix, tweak, and build upon the work non-commercially, as long as appropriate credit is given and the new creations are licensed under the identical terms.

For reprints contact: reprints@medknow.com

How to cite this article: Valenzuela R, Valenzuela D. Surface roughness implant-retained mandibular bar and ball joint overdentures and adherence of microorganisms. Eur J Dent 2018;12:546-52.

DOI: 10.4103/ejd.ejd_265_18 
from the polymerization of methacrylic acid or its derivatives. ${ }^{[7]}$ These polymethacrylates must be resistant to fracture and flexion, properties that can be increased through zirconia or amorphous silica particles. ${ }^{[8,9]}$ Possibly, the immersion of some oral restorations in agents cleaners alters their structural stability. ${ }^{[10]}$ It is considered that the absence of porosity and dimensional stability increases the surface quality of the restorations, influencing the preservation of the mucous tissues through surfaces that facilitate the patient's oral hygiene. Therefore, an important factor in reference to the quality of the mouth restorations is the surface roughness $\left(R_{\mathrm{a}}\right)$ with importance in the preservation of the oral health in relation to the surrounding tissue. ${ }^{[11-13]}$ There are differences in roughness values in various thermoplastic methacrylates. ${ }^{[14]}$ The surface quality of the restorations and their relationship with the gingival tissues enable smoother surfaces to maintain the health of oral tissues, avoiding the inflammation of them. The surfaces of the overdentures are available as substrates for the development and growth of microorganisms. The oral cavity presents more than 700 bacterial species, ${ }^{[15]}$ and overdentures implant-retained are susceptible to the accumulation of microorganisms with adhesion capacity such as mold and yeast and mesophyll aerobe. The yeasts are unicellular fungi which reproduce by budding and transverse division and the mold is formed by hyphae, the whole of which forms a mycelium. The mold and yeast which cause pathology in humans are dimorphic and $2-4 \mu \mathrm{m}$ in diameter ${ }^{[16]}$ Other microorganisms with adhesion capacity are mesophyll aerobes which include bacteria that develop in the presence of free oxygen of $0.5-2 \mu \mathrm{m}$ in diameter. ${ }^{[17,18]}$ The permanence of BOD and BJOD depends on several factors, one of them being the $R_{\mathrm{a}}$ and its relation with the adhesion of microorganisms. The objective of the study was to compare the $R_{\mathrm{a}}$ of $\mathrm{BOD}$ compared to BJOD in relation to the adhesion of mold and yeast and mesophyll aerobe at 30 and 180 days of permanence in the oral cavity in order to establish if there are differences in $R_{\mathrm{a}}$ and which of these overdentures are characterized by their lower roughness and adherence of mold and yeast and mesophyll aerobe, which is an important aspect to be considered in the rehabilitation of mandibular total edentulous patients with implants due to their influence on oral health.

\section{MATERIALS AND METHODS}

Thestudy presents theresults of a sample of ten patients randomly assigned to receive implant-retained overdentures and divided into two parallel groups of five participants in a single-blind trial at a follow-up period of 30 and 180 days permanence in the mouth. Five overdentures were made for each group: BOD: Five-systems titanium bar CARES ${ }^{\circledR}$ and synOcta ${ }^{\circledR}$ Straumann ${ }^{\circledR}$ Dental Implant System, Holding AG Inc., Basel, Switzerland (BOD). BJOD: Five-systems ball joint Klockner ${ }^{\circledR}$ Implant System; Soadco Inc., Escaldes-Engordany, Andorra, were used in two parallel groups of five participants, in an essay to simple blind (ClinicalTrials.gov: NCT03256409). The protocol was approved by the Institutional Review Boards affiliated with the researchers. All participants gave informed consent. The inclusion criteria of the patients for the study were total edentulous mandible from 50 to 60 years of age and absence of systemic conditions. The exclusion criteria of the patients for the study were hyperplasia and history of periodontal disease, patients with local and/or systemic antimicrobial treatment within $72 \mathrm{~h}$ prior to evaluation during the study, and signs of severe oral parafunction [Figure 1]. Selected patients underwent surgery with Tapered Effect Implants Straumann and Klockner Implant System. For the fabrication process of the overdentures in both groups, Lucitone $199{ }^{\circledR}$ (Dentsply International

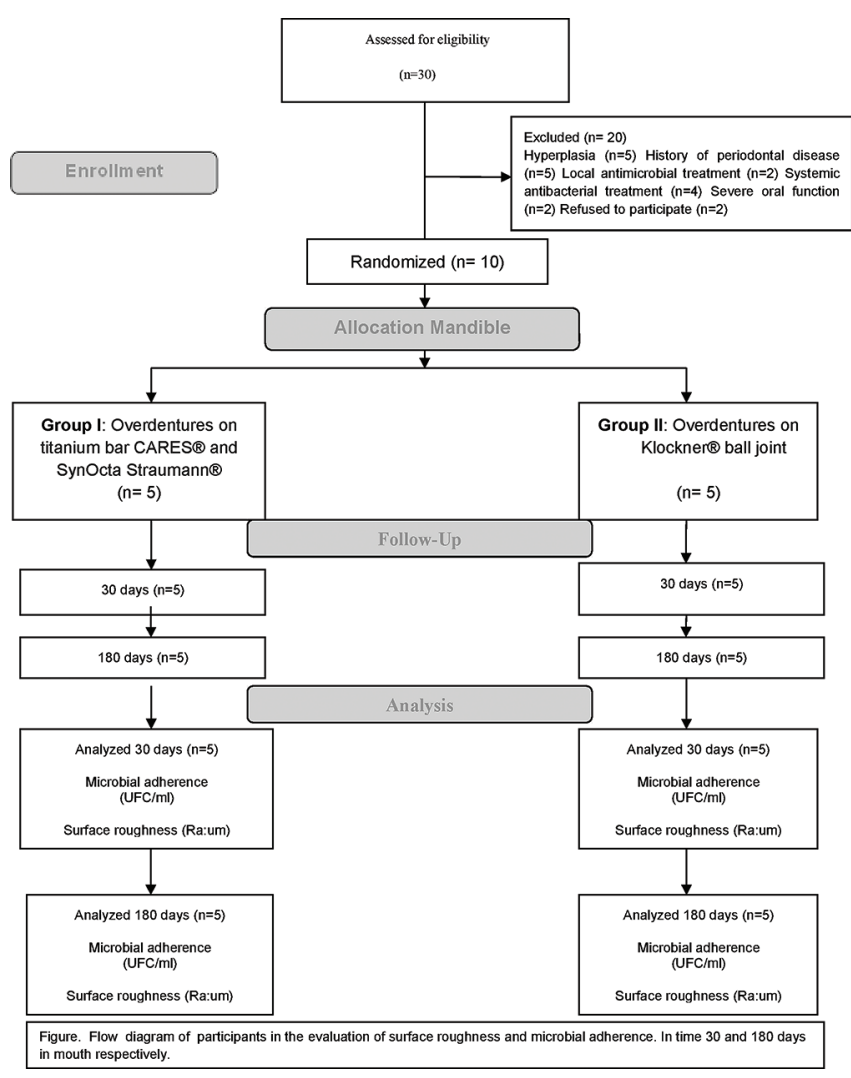

Figure 1: Flow diagram of participants in the evaluation of surface roughness and microbial adherence in time 30 and 180 days in mouth, respectively 
Inc., York, PA) was used as the material of choice and for the adaptation of the retention systems Softreliner Tough Soft ${ }^{\circledR}$ Tocuyama Dental Corporation Inc., Japan, was used. The working protocol for determining the BOD $R_{\mathrm{a}}$ and BJOD $R_{\mathrm{a}}$ and the adhesion of molds and yeasts and mesophyll aerobics was carried out entirely by the investigators and the following working methodology was considered: Information to the patient of the research work to be performed, obtainment of clinical data and patient informed consent. Patients were randomly assigned to Group 1 and Group 2. The saliva sample was obtained in each patient for the microbiological evaluation before the installation of the overdentures. BODs and BJODs were installed in each patient and according to each case. The BOD and BJOD were removed at 30 days for $R_{\mathrm{a}}$ evaluation $\left(R_{\mathrm{a}}: \mathrm{u} \mathrm{m}\right)$ and the evaluation of the adhesion of mold and yeast and mesophyll aerobe (colony-forming unit [CFU]/ml). For the study at 180 days, the BODs and the BJODs were installed in each patient. BODs and BJODs were removed after this time to proceed to the evaluation of $R_{\mathrm{a}}$ and adhesion of mold and yeast and mesophyll aerobe under the same parameters mentioned above.

Adherence mold and yeast and mesophyll aerobe to bar overdenture and bar joint overdenture, surface roughness, and statistical analyses

Microbial populations have been controlled in the saliva at initial time and adherence at 30 and 180 days after the overdentures in the mouth. The saliva sample was obtained from the patient in a sterile sputum collection bottle through a sterile solution. The overdenture samples were extracted and processed for analysis. Each sample was submerged in $1 / 4$ sterile Ringer and subjected to vigorous ultrasound shaking. From each of the microbial suspensions, successive dilutions were made to determine the total number of viable microorganisms present. Total count of mold and yeast and total count of mesophyll aerobe were performed.

The $R_{\mathrm{a}}$ of BOD and BJOD was determined with the Surfest SJ-301 ${ }^{\circledR}$ rugosimeter (Mitutoyo Corporation Inc., Kanagawa, Japan), through a displacement force of $4 \mathrm{mN}$ and of the tray to $0.5 \mathrm{~mm} / \mathrm{s}$ and back to $1 \mathrm{~mm} / \mathrm{s}^{\left[{ }^{[19]}\right.}$ The roughness profile $R_{\mathrm{a}}$ was evaluated and determined in microns (um) through five readings for each of the samples in the study.

The results of BOD and BJOD were compared for the determination of $R_{\mathrm{a}}$ and the adherence of mold and yeast and mesophyll aerobe. For this, we used the statistics Shapiro-Wilk test, $t$-test, and the Pearson's correlation coefficient to determinate the relationship between the study variables $(P<0.05)$ at $95 \%$ confidence interval. For data processing and analysis, the IBM Statistical Package for the Social Sciences, SPSS Statistics 24 (IBM ${ }^{\circledR}$ Company, Chicago, United States of America) was used.

\section{RESULTS}

The trial enrolled ten participants randomly assigned to $\operatorname{BOD}(n=5)$ and $\operatorname{BJOD}(n=5)$. All participants received treatments with overdentures according to the groups to which they were assigned. The average $R_{\mathrm{a}}$ BOD: 30 days was $0.965 \mu \mathrm{m}(0.937-0.992)$ at $95 \%$ confidence interval. The average $R_{\mathrm{a}}$ BOD: 180 days was $1.351 \mu \mathrm{m}(1.223-1.479)$ at $95 \%$ confidence interval. The correlation of independent test $(P<0.05)$ showed that BODs present different $R_{\mathrm{a}}$ at 30 and 180 days [Table 1]. The average $R_{\mathrm{a}}$ BJOD: 30 days was $1.325 \mu \mathrm{m}$ (1.262-1.389) at $95 \%$ confidence interval. The average $R_{\mathrm{a}}$ BJOD: 180 days was $2.384 \mu \mathrm{m}(2.216-2.55)$ at $95 \%$ confidence interval. The correlation of independent test $(P<0.05)$ showed that BJODs present different $R_{\mathrm{a}}$ in 30 and 180 days [Table 2].

\begin{tabular}{|c|c|c|c|c|c|c|c|}
\hline Group & $95 \% \mathrm{Cl}$ & Statistical & Dv & Shapiro-Wilk (significant) & Levene (significant) & $T$ significant (bilateral) & $95 \% \mathrm{Cl}$ \\
\hline \multirow{4}{*}{$\begin{array}{l}R_{\mathrm{a}} \text { Group 1: } \\
30 \text { days }\end{array}$} & Mean & 0.965 & 0.02217 & 0.940 & 0.005 & 0.000 & \\
\hline & $95 \% \mathrm{Cl}$ & ? & & & & & \\
\hline & Lower limit & 0.937 & & & & & -0.495216 \\
\hline & Upper limit & 0.992 & & & & & -0.277984 \\
\hline \multirow{4}{*}{$\begin{array}{l}R_{\mathrm{a}} \text { Group } 1: \\
180 \text { days }\end{array}$} & Mean & 1.351 & 0.10296 & 0.000 & 0.398 & 0.005 & 0.001 \\
\hline & $95 \% \mathrm{Cl}$ & & & & & & \\
\hline & Lower limit & 1.223 & & & & & -0.513121 \\
\hline & Upper limit & 1.479 & & & & & -0.260079 \\
\hline
\end{tabular}


The average value of adherence of mold and yeast for BOD: 30 days was $2.6 \times 10^{2} \mathrm{CFU} / \mathrm{ml}\left(2.3 \times 10^{2}-2.9 \times 10^{2}\right)$ at $95 \%$ confidence interval. The mean initial salivary count was $1.2 \times 10^{2} \mathrm{CFU} / \mathrm{ml}$. For BJOD: 30 days it was $3.0 \times 10^{2} \mathrm{CFU} / \mathrm{ml}\left(2.7 \times 10^{2}-3.2 \times 10^{2}\right)$ at $95 \%$ confidence interval. The mean initial saliva count was $1.1 \times 10^{2} \mathrm{CFU} / \mathrm{ml}$. The independent test correlation $(P>0.05)$ indicated that BOD and BJOD did not exhibit different adherence of mold and yeast at 30 days. The average value of adherence of mold and yeast for BOD: 180 days was $4.6 \times 10^{3} \mathrm{CFU} / \mathrm{ml}$ $\left(4.0 \times 10^{3}-5.1 \times 10^{3}\right)$ at $95 \%$ confidence interval. For BJOD: 180 days was $5.3 \times 10^{4} \mathrm{CFU} / \mathrm{ml}\left(4.8 \times 10^{4}-5.7 \times 10^{4}\right)$ at $95 \%$ confidence intervals. The independent test correlation $(P<0.05)$ indicated that BOD and BJOD exhibit different adhesion of mold and yeast to 180 days. At 30 days of study, there were no differences in $R_{\mathrm{a}}$ and adherence of mold and yeast between BOD and BJOD $(P=0.489)$. At 180 days of study, there were differences in $R_{\mathrm{a}}$ and adherence of mold and yeast between BOD and BJOD $(P=0.723)$ [Table 3].

The mean adherence value of mesophyll aerobe for BOD: 30 days was $3.8 \times 10^{6} \mathrm{CFU} / \mathrm{ml}\left(3.3 \times 10^{6}-4.2 \times 10^{6}\right)$ at $95 \%$ confidence intervals. The mean initial saliva count was $2.2 \times 10^{6} \mathrm{CFU} / \mathrm{ml}$. For BJOD: 30 days was $4.3 \times 10^{6} \mathrm{CFU} / \mathrm{ml}\left(3.8 \times 10^{6}-4.8 \times 10^{6}\right)$ and the mean initial saliva count was $2.4 \times 10^{6} \mathrm{CFU} / \mathrm{ml}$. The correlation of independent test $(P>0.05)$ indicated that BOD and BJOD do not exhibit different adherence

\begin{tabular}{|c|c|c|c|c|c|c|c|}
\hline Group & $95 \% \mathrm{Cl}$ & Statistical & Dv & Shapiro-Wilk (significant) & Levene (significant) & $T$ significant (bilateral) & $95 \% \mathrm{Cl}$ \\
\hline \multirow{4}{*}{$\begin{array}{l}R_{\mathrm{a}} \text { Group 2: } \\
30 \text { days }\end{array}$} & Mean & 1.325 & 0.050923 & 0.272 & 0.087 & 0.000 & \\
\hline & $95 \% \mathrm{Cl}$ & & & & & & \\
\hline & Lower limit & 1.262 & & & & & -1.207621 \\
\hline & Upper limit & 1.389 & & & & & -0.909179 \\
\hline \multirow{4}{*}{$\begin{array}{l}R_{\mathrm{a}} \text { Group } 2: \\
180 \text { days }\end{array}$} & Mean & 2.384 & 0.135439 & 0.967 & 0.087 & 0.000 & \\
\hline & $95 \% \mathrm{Cl}$ & & & & & & \\
\hline & Lower limit & 2.216 & & & & & -1.223683 \\
\hline & Upper limit & 2.552 & & & & & -0.893117 \\
\hline
\end{tabular}

\begin{tabular}{|c|c|c|c|c|c|c|c|}
\hline Group & $95 \% \mathrm{Cl}$ & Statistical & Dv & $\begin{array}{l}\text { Shapiro-Wilk } \\
\text { (significant) }\end{array}$ & $\begin{array}{c}\text { Levene } \\
\text { (significant) }\end{array}$ & $\begin{array}{c}T \text { significant } \\
\text { (bilateral) }\end{array}$ & Pearson $\left(R_{\mathrm{a}}\right)$ \\
\hline \multirow{4}{*}{$\begin{array}{l}\text { Adherence } \\
\text { Mold and Yeast } \\
\text { Group 1: } 30 \text { days }\end{array}$} & Mean & 2.6 & 0.2702 & 0.427 & 0.744 & 0.051 & \multirow{4}{*}{0.489} \\
\hline & $95 \% \mathrm{Cl}$ & & & & & & \\
\hline & Lower limit & 2.3 & & & & & \\
\hline & Upper limit & 2.9 & & & & & \\
\hline \multirow{4}{*}{$\begin{array}{l}\text { Adherence } \\
\text { Mold and Yeast } \\
\text { Group 2: } 30 \text { days }\end{array}$} & Mean & 3.0 & 0.2236 & 1.000 & 0.744 & 0.052 & \multirow{4}{*}{0.489} \\
\hline & $95 \% \mathrm{Cl}$ & & & & & & \\
\hline & Lower limit & 2.7 & & & & & \\
\hline & Upper limit & 3.2 & & & & & \\
\hline \multirow{4}{*}{$\begin{array}{l}\text { Adherence } \\
\text { Mold and } \\
\text { Yeast Group 1: } \\
180 \text { days }\end{array}$} & Mean & 4.6 & 0.4690 & 0.795 & 0.501 & 0.025 & \multirow{5}{*}{$0.723^{*}$} \\
\hline & $95 \% \mathrm{Cl}$ & & & & & & \\
\hline & Lower limit & 4.0 & & & & & \\
\hline & Upper limit & 5.1 & & & & & \\
\hline \multirow{4}{*}{$\begin{array}{l}\text { Adherence } \\
\text { Mold and } \\
\text { Yeast Group 2: } \\
180 \text { days }\end{array}$} & Mean & 5.3 & & & & & \\
\hline & $95 \% \mathrm{Cl}$ & & 0.3493 & 0.976 & 0.501 & 0.027 & \multirow{3}{*}{$0.723^{*}$} \\
\hline & Lower limit & 4.8 & & & & & \\
\hline & Upper limit & 5.7 & & & & & \\
\hline \multicolumn{8}{|c|}{$\begin{array}{l}\text { Average adhesion values of mold and yeast. Group } 1 \text { (BOD): } 30 \text { days: } 2.6 \times 10^{2} \mathrm{CFU} / \mathrm{ml} \text {. Group } 2 \text { (BJOD): } 30 \text { days: } 3.0 \times 10^{2} \mathrm{CFU} / \mathrm{ml} \text {. Group } 1 \text { (BOD): } 180 \text { days: } 4.6 \\
\times 10^{3} \mathrm{CFU} / \mathrm{ml} \text {. Group } 2 \text { (BJOD): } 180 \text { days: } 5.3 \times 10^{4} \mathrm{CFU} / \mathrm{ml} .95 \% \text { confidence and Shapiro-Wilk }(P>0.05) \text {, determines normal distribution. Correlation of independent } \\
\text { tests } 30 \text { days }(P>0.05) \text { BOD }(P=0.051) \text { and BJOD }(P=0.052) \text { showed no different adherence. For } 180 \text { days }(P<0.05), \mathrm{BOD}(P=0.025) \text { and BJOD }(P=0.027) \text { presented } \\
\text { different adhesion. }{ }^{*} \text { The correlation is significant at the } 0.05 \text { level (bilateral). At } 30 \text { days of study, there were no differences in } R_{\mathrm{a}} \text { and adherence of mold and yeast } \\
\text { and mesophyll aerobe }(P=0.489) \text {. At } 180 \text { days of study, there were differences in } R_{\mathrm{a}} \text { and adherence of mold and yeast and mesophyll aerobics }(P=0.723) \text {. BOD: } \\
\text { Bar overdenture, BJOD: Ball joint overdenture, Cl: Confidence interval, CFU: Colony-forming unit }\end{array}$} \\
\hline
\end{tabular}


of mold and yeast at 30 days. The mean adherence value of mesophyll aerobe in Group 1: 180 days was $5.8 \times 10^{6} \mathrm{CFU} / \mathrm{ml}\left(5.6 \times 10^{6}-6.1 \times 10^{6}\right)$ at $95 \%$ confidence interval. In Group 2: 180 days was $7.1 \times 10^{7} \mathrm{CFU} / \mathrm{ml}$ $\left(6.8 \times 10^{7}-7.4 \times 10^{7}\right)$ at $95 \%$ confidence interval. The independent test correlation $(P<0.05)$ indicated that BOD and BJOD exhibited different adherence of mesophyll aerobe at 180 days. At 30 days of study, there were no differences in $R_{\mathrm{a}}$ and adherence of mesophyll aerobe between BOD and BJOD $(P=0.489)$. At 180 days of study, there were differences in $R_{\mathrm{a}}$ and adherence of mesophyll aerobe between BOD and BJOD $(P=0.723)$ [Table 4].

\section{DISCUSSION}

The trial included ten participants randomly into two parallel groups of five participants each to receive implant-retained overdentures such as $\mathrm{BOD}=5$ and $\mathrm{BJOD}=5$ in a single-blind trial. The sample is limited by the inclusion and exclusion criteria considered for the present study as a function of time during 30 and 180 days of permanence in the mouth. The average results of $R_{\mathrm{a}}$ in the BOD showed increases in $R_{\mathrm{a}}$ as a function of time. This roughness is increased possibly due to the physical structural changes in the structure of the polymethacrylate of the overdenture, which increases its porosity when exposed to oral fluids, and acidic or basic solutions and changes in temperature in foods, including chewing that would decrease the hardness of these structures. ${ }^{[1,12,20]}$ Increases of $R_{\mathrm{a}}$ have been found in restorations based on polymethacrylates when stored in vitro. ${ }^{[11]}$ Increases in $R_{\mathrm{a}}$ would alter surface properties. ${ }^{[12]}$ The chewing of food, brushing, and toothpaste and cleaning agents cause abrasion of the surfaces of the restorations, making them rougher. ${ }^{[10,21,22]}$ However, the physical structure of the polymers has a chain length which increases stiffness and resistance to solvents. ${ }^{[7]}$ The average $R_{\mathrm{a}}$ measurement in BJOD showed the highest increase at 30 and 180 days. If we compare the results, the $\mathrm{BJODs}$ have a $R_{\mathrm{a}}$ average greater than $\mathrm{BOD}$. This is possibly due to the structural changes of BJOD caused by the imbibition process with the absorption of water in relatively small quantities. This process could have significant effects on the mechanical and dimensional properties in the structure of BJOD. In addition, the polarity of the polymethacrylate molecules facilitates the absorption of water by molecular diffusion so that the water molecules penetrate the polymer chains causing their separation and expansion. This process probably increased the BJOD $R_{a}$. Another possible explanation for the increase of $R_{a}$ in the polymethacrylate-based overdenture is the median fracture and flexural strength of these polymers. ${ }^{[7]}$ Some authors recommend increasing the resistance

\begin{tabular}{|c|c|c|c|c|c|c|c|}
\hline Group & $95 \% \mathrm{Cl}$ & Statistical & Dv & $\begin{array}{l}\text { Shapiro-Wilk } \\
\text { (significant) }\end{array}$ & $\begin{array}{c}\text { Levene } \\
\text { (significant) }\end{array}$ & $\begin{array}{c}T \text { significant } \\
\text { (bilateral) }\end{array}$ & Pearson $\left(R_{\mathrm{a}}\right)$ \\
\hline \multirow{4}{*}{$\begin{array}{l}\text { Adherence } \\
\text { mesophyll aerobe } \\
\text { Group 1: } 30 \text { days }\end{array}$} & Mean & 3.8 & 0.3421 & 0.814 & 0.541 & 0.052 & \\
\hline & $95 \% \mathrm{Cl}$ & & & & & & \\
\hline & Lower limit & 3.3 & & & & & 0.489 \\
\hline & Upper limit & 4.2 & & & & & \\
\hline \multirow{4}{*}{$\begin{array}{l}\text { Adherence } \\
\text { mesophyll aerobe } \\
\text { Group 2: } 30 \text { days }\end{array}$} & Mean & 4.3 & 0.4037 & 0.708 & 0.541 & 0.053 & \\
\hline & $95 \% \mathrm{Cl}$ & & & & & & \\
\hline & Lower limit & 3.8 & & & & & 0.489 \\
\hline & Upper limit & 4.8 & & & & & \\
\hline \multirow{4}{*}{$\begin{array}{l}\text { Adherence } \\
\text { mesophyll aerobe } \\
\text { Group 1: } 180 \text { days }\end{array}$} & Mean & & & & & & \\
\hline & $95 \% \mathrm{Cl}$ & & & & & & \\
\hline & Lower limit & & & & & & $0.723^{*}$ \\
\hline & Upper limit & & & & & & \\
\hline \multirow{4}{*}{$\begin{array}{l}\text { Adherence } \\
\text { mesophyll aerobe } \\
\text { Group 2: } 180 \text { days }\end{array}$} & Mean & 7.1 & 0.2387 & 0.899 & 0.593 & 0.000 & \\
\hline & $95 \% \mathrm{Cl}$ & & & & & & \\
\hline & Lower limit & 6.8 & & & & & $0.723^{*}$ \\
\hline & Upper limit & 7.4 & & & & & \\
\hline \multicolumn{8}{|c|}{$\begin{array}{l}\text { Average adhesion values of mesophyll aerobe. Group } 1 \text { (BOD): } 30 \text { days: } 3.8 \times 10^{6} \mathrm{CFU} / \mathrm{ml} \text {. Group } 2 \text { (BJOD): } 30 \text { days: } 4.3 \times 10^{6} \mathrm{CFU} / \mathrm{ml} \text {. Group } 1 \text { (BOD): } 180 \text { days: } \\
5.8 \times 10^{6} \mathrm{CFU} / \mathrm{ml} \text {. Group } 2 \text { (BJOD): } 180 \text { days: } 7.1 \times 10^{7} \mathrm{CFU} / \mathrm{ml} .95 \% \text { confidence and Shapiro-Wilk }(P>0.05) \text {, determines normal distribution. Correlation of independent } \\
\text { tests } 30 \text { days }(P>0.05) \text { BOD }(P=0.052) \text { and BJOD }(P=0.053) \text { showed no different adherence. For } 180 \text { days }(P<0.05), \mathrm{BOD}(P=0.000) \text { and BJOD }(P=0.000) \text { presented } \\
\text { different adhesion. }{ }^{*} \text { The correlation is significant at the } 0.05 \text { level (bilateral). At } 30 \text { days of study, there were no differences in } R_{\mathrm{a}} \text { and adherence of mold and yeast } \\
\text { and mesophyll aerobe }(P=0.489) \text {. At } 180 \text { days of study, there were differences in } R_{\mathrm{a}} \text { and adherence of mold and yeast and mesophyll aerobics }(P=0.723) \text {. BOD: } \\
\text { Bar overdenture, BJOD: Ball joint overdenture, Cl: Confidence interval, CFU: Colony-forming unit, } R_{\mathrm{a}} \text { : Surface roughness }\end{array}$} \\
\hline
\end{tabular}


and hardness properties of polymethacrylates. ${ }^{[8,9]}$ The total count of mold and yeast in BOD and BJOD shows increases from the initial time to 30 and 180 days. Comparing these data establishes an increase of the population mean in BOD and BJOD in relation to the exposure time. Our results are related to in vitro studies that tested the adhesion of mold and yeast to materials based on polymethacrylates. ${ }^{[23]}$ In addition, in vitro studies showed more adhesion of mold and yeast to materials based on polymethacrylates compared to metals and fiberglass. On the other hand, the saliva decreases the adhesion of all the yeasts to the surfaces of methacrylates, whereas the $R_{\mathrm{a}}$ does not interfere with the adherence of these species. ${ }^{[13,24]}$ Wetter surfaces of polymethacrylates would cause adherence of mold and yeast species, ${ }^{[16,25-27]}$ a property that could justify the increase of the mold and yeast population in BJOD. However, we considered that the $R_{\mathrm{a}}$ of the overdentures would be more associated to the adhesion of mold and yeast and that the adhesion of these species is greater in rough surfaces than in smooth surfaces. Considering that polymethacrylates are not bacteriostatic and that in vitro studies suggest that the $R_{\mathrm{a}}$ threshold for bacterial retention is $R_{\mathrm{a}}=0.2 \mu$, it is suggested that if there were an increase in roughness surface, bacterial plaque accumulation would also increase. ${ }^{[13,24]}$ In reference to the adhesion of mesophyll aerobe in BOD and BJOD, these increase from initial time to 30 and 180 days. These results allow us to determine that both types of overdentures present an increase in the adhesion of mesophyll aerobe. Comparing these data, an increase in the population average is established, which presents its highest number at 180 days. This is probably due to the structural properties of imbibition, lower strength, and higher porosity, which probably increase the $R_{a}$ that allows the adhesion of mesophyll aerobe in greater quantity. Mesophyll aerobe uses hydrogen peroxide from salivary sediments and dental plaque, ${ }^{[15,28,29]}$ in such a way that by the mechanism of absorption of water obtained from the saliva, they facilitate their predilection by this substrate. The proximity to the oral tissues would allow greater adhesion to BJOD, and the high proportion of mesophyll aerobe would be explained by its property of bacteriostatic inhibition for other species. ${ }^{[17]}$ In addition, if we observe that the BODs have a $R_{\mathrm{a}}: 0.965 \mu \mathrm{m}$ at 30 days and $1.351 \mu \mathrm{m}$ at 180 days in comparison to BJOD that have a $R_{a}: 1.325$ $\mu \mathrm{m}$ at 30 days and $2.384 \mu \mathrm{m}$ at 180 days and we related these results to the dimensions of the mesophyll aerobe in approximately $0.5-2 \mu \mathrm{m}$, it is possible that these microorganisms adhere more efficiently to BJOD because they would find niches that allow them to withstand the cutting forces such as chewing and swallowing, favoring their retention. Polymers exhibit increases in colonization by mesophyll aerobe $^{[17,30]}$ and saliva does not interfere with the adhesion of these microorganisms to the surfaces of the oral cavity. ${ }^{[18]}$ Prevalence of nutritional conditions during cutting- forces. ${ }^{[28]}$ In addition, less plaque has been reported in hydrophobic polymers than in hydrophilic polymers. ${ }^{[27,31]}$ Other in vitro studies have shown high adherence of mesophyll aerobe in polymethylmethacrylate intraocular lenses, ${ }^{[30,31]}$ sanded surfaces, and steel ${ }^{[23]}$ saliva and tongue associated with gingivitis ${ }^{[28]}$ and periodontitis. ${ }^{[29]}$

The structures of the buccal cavity contain various microbial species. ${ }^{[23,28]}$ BODs and BJODs, as observed in our study, are surfaces available in the oral cavity for the adhesion of mold and yeast and mesophyll aerobe. The adhesion of these microorganisms to these implant-retained mandibular overdentures found in our study could be related to those reported by Waltimo et al. ${ }^{[25]}$ who found retention of microorganisms in polymethacrylates. In our study, BODs and BJODs have been used because of their acceptable properties, characteristics, manufacturing methods, and structure, which make them eligible for the rehabilitation of total edentulous patients of the lower jaw. ${ }^{[1-6]}$ By the other side, studies have been made of materials and $R_{\mathrm{a}}$ measurement techniques in order to achieve an adequate surface quality which will influence esthetics and their relationship with oral tissues. ${ }^{[14]}$

\section{CONCLUSIONS}

The evaluation of the ten participants was limited by the study criteria. Parallel treatments were assigned with ball implant-retained overdenture (BOD) and ball joint implant-retained overdenture (BJOD). BJOD presented different $R_{\mathrm{a}}$ values at 30 and 180 days of study, being higher in BJOD. The higher $R_{\mathrm{a}}$ average in BJOD is possibly due to the structural changes of its polymers caused by imbibition and proximity to the oral tissues allowing the absorption of water, which would exert significant effects on the mechanical and dimensional properties of the polymer. In reference to the adhesion of mold and yeast and mesophyll aerobe in BOD and BJOD, they did not present different adherence at 30 days but did present differences in adhesion for 180 days. The BJOD presented greater adhesion of mold and yeast and mesophyll aerobe. It is likely that the $R_{\mathrm{a}}$ of polymethacrylate-based overdentures will influence more than other factors in the adhesion of mold and yeast and mesophyll aerobe. 
The rougher surfaces will have a greater impact on the adhesion and retention of microorganisms, causing a faster colonization of the surfaces of both types of overdentures, increasing the risk to mucosal tissue infections. However, this characteristic could be associated to the effect of the structural nature of the overdentures to explain the mechanisms of adhesion of mold and yeast and mesophyll aerobe to these surfaces, with clinical importance in the preservation of oral health of the total edentulous of the mandible rehabilitated with overdentures.

\section{Acknowledgments}

The authors thank the participants, as well as Ida Narvaez Ph.D, scientific advisor.

\section{Financial support and sponsorship Nil}

\section{Conflicts of interest}

There are no conflicts of interest.

\section{REFERENCES}

1. Stellingsma K, Slagter AP, Stegenga B, Raghoebar GM, Meijer HJ. Masticatory function in patients with an extremely resorbed mandible restored with mandibular implant-retained overdentures: Comparison of three types of treatment protocols. J Oral Rehabil 2005;32:403-10.

2. Portmann M, Glauser R. Report of a case receiving full-arch rehabilitation in both jaws using immediate implant loading protocols: A 1-year resonance frequency analysis follow-up. Clin Implant Dent Relat Res 2006;8:25-31.

3. Visser A, Meijer HJ, Raghoebar GM, Vissink A. Implant-retained mandibular overdentures versus conventional dentures: 10 years of care and aftercare. Int J Prosthodont 2006;19:271-8.

4. Degidi M, Piattelli A. Immediately loaded bar-connected implants with an anodized surface inserted in the anterior mandible in a patient treated with diphosphonates for osteoporosis: A case report with a 12-month follow-up. Clin Implant Dent Relat Res 2003;5:269-72.

5. Elsyad MA, Ashmawy TM, Faramawy AG. The influence of resilient liner and clip attachments for bar-implant-retained mandibular overdentures on opposing maxillary ridge. A 5-year randomised clinical trial. J Oral Rehabil 2014;41:69-77.

6. van Kampen F, Cune M, van der Bilt A, Bosman F. Retention and postinsertion maintenance of bar-clip, ball and magnet attachments in mandibular implant overdenture treatment: An in vivo comparison after 3 months of function. Clin Oral Implants Res 2003;14:720-6.

7. Lang R, Rosentritt M, Behr M, Handel G. Fracture resistance of PMMA and resin matrix composite-based interim FPD materials. Int J Prosthodont 2003;16:381-4.

8. Panyayong W, Oshida Y, Andres CJ, Barco TM, Brown DT, Hovijitra S, et al. Reinforcement of acrylic resins for provisional fixed restorations. Part III: Effects of addition of Titania and zirconia mixtures on some mechanical and physical properties. Biomed Mater Eng 2002;12:353-66.

9. Uzun G, Keyf F. The effect of fiber reinforcement type and water storage on strength properties of a provisional fixed partial denture resin. J Biomater Appl 2003;17:277-86.

10. Senna P, Vieira AP, Sotto-Maior B, Da Silva W, Cury A. Influence of inmersion time of denture cleansers on the surface roughness of resilient denture liners. Rev Odontol Cienc 2011;26:35-9.

11. Yap AU, Mah MK, Lye CP, Loh PL. Influence of dietary simulating solvents on the hardness of provisional restorative materials. Dent Mater 2004;20:370-6.

12. Guler AU, Yilmaz F, Kulunk T, Guler E, Kurt S. Effects of different drinks on stainability of resin composite provisional restorative materials. J Prosthet Dent 2005:94:118-24.

13. Bollen CM, Lambrechts P, Quirynen M. Comparison of surface roughness of oral hard materials to the threshold surface roughness for bacterial plaque retention: A review of the literature. Dent Mater 1997;13:258-69.

14. Berger JC, Driscoll CF, Romberg E, Luo Q, Thompson G. Surface roughness of denture base acrylic resins after processing and after polishing. J Prosthodont 2006;15:180-6.

15. Busscher HJ, van der Mei HC. Physico-chemical interactions in initial microbial adhesion and relevance for biofilm formation. Adv Dent Res 1997;11:24-32.

16. Radford DR, Challacombe SJ, Walter JD. Denture plaque and adherence of Candida albicans to denture-base materials in vivo and in vitro. Crit Rev Oral Biol Med 1999;10:99-116.

17. Daniluk T, Fiedoruk K, Sciepuk M, Zaremba ML, Rozkiewicz D, Cylwik-Rokicka D, et al. Aerobic bacteria in the oral cavity of patients with removable dentures. Adv Med Sci 2006;51 Suppl 1:86-90.

18. Busscher HJ, Uyen MH, van Pelt AW, Weerkamp AH, Arends J. Kinetics of adhesion of the oral bacterium Streptococcus sanguis $\mathrm{CH} 3$ to polymers with different surface free energies. Appl Environ Microbiol 1986;51:910-4.

19. Murtra I, Montalvillo A, Arcís RW, Murtra J. Mitutoyo Roughmeter. Surftest 301 Model. Dentum; 1999. p. 31-7.

20. Keyf F, Etikan I. Evaluation of gloss changes of two denture acrylic resin materials in four different beverages. Dent Mater 2004;20:244-51.

21. Mendonça MJ, Machado AL, Giampaolo ET, Pavarina AC, Vergani CE. Weight loss and surface roughness of hard chairside reline resins after toothbrushing: Influence of postpolymerization treatments. Int J Prosthodont 2006;19:281-7.

22. Richmond R, Macfarlane TV, McCord JF. An evaluation of the surface changes in PMMA biomaterial formulations as a result of toothbrush/dentifrice abrasion. Dent Mater 2004;20:124-32.

23. Brusca MI, Chara O, Sterin-Borda L, Rosa AC. Influence of different orthodontic brackets on adherence of microorganisms in vitro. Angle Orthod 2007:77:331-6.

24. Quirynen M, Bollen CM. The influence of surface roughness and surface-free energy on supra - And subgingival plaque formation in man. A review of the literature. J Clin Periodontol 1995;22:1-4.

25. Waltimo T, Tanner J, Vallittu P, Haapasalo M. Adherence of Candida albicans to the surface of polymethylmethacrylate - E glass fiber composite used in dentures. Int J Prosthodont 1999;12:83-6.

26. He XY, Meurman JH, Kari K, Rautemaa R, Samaranayake LP. In vitro adhesion of Candida species to denture base materials. Mycoses 2006;49:80-4.

27. Yildirim MS, Hasanreisoglu U, Hasirci N, Sultan N. Adherence of Candida albicans to glow-discharge modified acrylic denture base polymers. J Oral Rehabil 2005;32:518-25.

28. Ryan CS, Kleinberg I. Bacteria in human mouths involved in the production and utilization of hydrogen peroxide. Arch Oral Biol 1995;40:753-63

29. Tada A, Watanabe T, Yokoe H, Hanada N, Tanzawa H. Oral bacteria influenced by the functional status of the elderly people and the type and quality of facilities for the bedridden. J Appl Microbiol 2002;93:487-91.

30. Pinna A, Zanetti S, Sechi LA, Carta F. In vitro adherence of Staphylococcus epidermidis, Serratia marcescens, and Pseudomonas aeruginosa to AcrySof intraocular lenses. J Cataract Refract Surg 2005;31:2430-1.

31. Shimizu K, Kobayakawa S, Tsuji A, Tochikubo T. Biofilm formation on hydrophilic intraocular lens material. Curr Eye Res 2006;31:989-97. 